\title{
New Plant Type Mutants in Jute (Corchorus olitorius L.)
}

\author{
Aninda Mandal and Animesh Kumar Datta* \\ Department of Botany, Cytogenetics, Genetics and Plant Breeding Section, Kalyani University \\ Kalyani-741235, West Bengal, India; dattaanimesh@gmail.com
}

\begin{abstract}
Three macromutants namely, 'pigmented stem', 'viridis' and 'lax branching', of jute (Corchorus olitorius L. - JRO 524; commercial fibre yielding crop) were induced at $\mathrm{M}_{2}$ following gamma irradiations and EMS (Ethyl Methane Sulphonate) treatments. The true breeding mutants (selfed seeds of a single phenotypically stable plant forwarded in each generation from $\mathrm{M}_{4}$ ) are assessed considering different attributes like germination, survivability, meiotic chromosome behavior, pollen fertility and viability and quantitative traits across the generations $\left(\mathrm{M}_{5}, \mathrm{M}_{6}\right.$ and $\left.\mathrm{M}_{7}\right)$ in relation to control under a uniform field condition(s). Further, genetic variations between/among the mutants and between mutant(s) and control is also analyzed from seed protein (SDS-PAGE - sodium dodecyl sulphate-polyacrylamide gel electrophoresis), RAPD (Random Amplification of Polymorphic DNA) and ISSR (inter-simple sequence repeat) profiles. Pigment profiles following TLC (Thin Layer Chromatography) have been studied in 'viridis' and control. Inheritance of the mutant trait(s) has also been assessed from reciprocal crossings performed between control and mutants. Results suggest that the mutants are true breeding, stable and significant and may enrich genetic resources in the species.
\end{abstract}

Keywords: C. olitorius, Genetic Distinctiveness, Macromutants, Marker Traits, Stability

\section{Introduction}

Induced mutagenesis is a potent tool for widening gene pool in a species through creation of genetic variations in a short span of time. Experimentally induced mutation has contributed significantly to global agriculture by producing more than 3000 mutants with desirable qualitative and quantitative traits in about 175 crop species ${ }^{1}$. Jute is an important crop species (Corchorus capsularis $\mathrm{L}$ - white jute, C. olitorius L. - tossa jute; once classified with the family Tiliaceae, more recently with Malvaceae, and has now been reclassified as belonging to the family Sparrmanniaceae) yield fiber of commerce (common name pat ${ }^{2}$ ) from bark of the stem (phloem fiber). A good number of elite 'plant type' mutants are reported in C. capsularis $^{3-6}$ as well as in C. olitorius ${ }^{4,5,7}$ but it is always desirable to raise superior mutants of economic worth by exploring the existing germplasm(s).

Maity and Datta ${ }^{8}$ raised 3 plant type mutants in C. olitorius namely, 'pigmented stem', 'viridis' and 'lax branching' following gamma irradiation and EMS treatments. Present communication describes the mutants in advance generations $\left(\mathrm{M}_{5}\right.$ to $\left.\mathrm{M}_{7}\right)$ upon considering parameters namely, germinability, morphometric traits, meiosis, pollen fertility and viability and seed viability for ascertaining stability of the raised plant types. Further, seed protein (SDS-PAGE - sodium dodecyl sulphatepolyacrylamide gel electrophoresis) profile and RAPD and ISSR (Inter-Simple Sequence Repeat) molecular markers are used for genetic characterization of the mutants in relation to control. The objective of the work is to recommend new, stable and true breeding germplasm resources in C. olitorius that may be beneficial for commerce as well as for efficient breeding.

\section{Materials and Methods}

\subsection{Germplasms}

Selfed seeds of true breeding $M_{4}$ mutants (raised at $M_{2}$ following gamma irradiations and EMS treatments) namely, 'pigmented stem', 'viridis' and 'lax branching' (selfed seeds of a phenotypically stable plant in each case were forwarded in each generation to avoid genetic

*Author for correspondence 
contamination) along with selfed control lines (C. olitorius L. - JRO 524; mother seed stock obtained from CRIJAF Central Research Institute for Jute and Allied Fibres, Nilganj, Kolkata, West Bengal, India in the year 2006) were used as germplasm source. In each generation, the plant types were grown in randomized block design with 3 replications (plot size: $3 \mathrm{~m} \times 1.5 \mathrm{~m}$, between plants 30 $\mathrm{cm}$ and rows $20 \mathrm{~cm}$ ) in the experimental field plots of Department of Botany, University of Kalyani (West Bengal plains, Nadia; latitude $22^{\circ} 50^{\prime}$ to $24^{\circ} 11^{\prime} \mathrm{N}$, longitude $88^{\circ} 09^{\prime}$ to $88^{\circ} 48^{\prime}$ E, elevation 48 feet above sea level, sandy loamy soil, organic carbon $0.76 \%$, soil $\mathrm{pH} 6.85$ ) as rabi crop from March to October (2010-2012). No fertilizer application was made during growth periods of the plant types.

\subsection{Quantitative Parameters}

Germination frequency, quantitative morphological parameters and seed viability were analyzed in the plant types across generations. Morphometric quantitative traits were assessed on harvest. On an average 20 to 25 randomly selected plants were analyzed for quantitative parameters in each plant type and in each generation. $\chi^{2}$ test of heterogeneity (DF 2) has been performed for each quantitative trait to assess variations, if any, among the years. Viability of seeds was tested following $1 \%$ tetrazolium chloride method'.

Fibre yield in the plant types was estimated following the conventional method of whole plant retting. For this purpose, defoliated plants of mutants and control were dipped in stagnant pond water. Brick bats tied in cement bags were used to deep the jak materials. Retting was completed within 20 days and fibre has been extracted by "beat-break-jerk" method.

\subsection{Meiosis and Pollen Grains Attributes}

For the meiotic studies, 3 to 4 floral buds of each plant types (control and 3 mutants) of each generation $\left(M_{5}\right.$ to $\mathrm{M}_{7}$ ) were fixed (6 am to $7 \mathrm{am}$ ) in Carnoy's solution (6 ethanol : 3 chloroform : 1 acetic acid) and 2 to 3 changes were given in the fixative at an interval of 24 hours and preserved in $70 \%$ alcohol. Pollen mother cells (PMCs) and pollen grains obtained from anther squash preparations were stained in $2 \%$ propinocarmine solution. Fully stained pollen grains were considered fertile ${ }^{10}$. Data were scored from scattered diplotene, metaphase I (MI) and anaphase I (AI) cells and pooled over the buds for each plant type in each generation.
Viability of the pollen grains in each plant type was tested using stain tests namely, aniline blue in lacto phenol (detects the presence of callose on pollen wall, viable pollen turns blue ${ }^{11}$ ) and FDA - Fluorescein Diacetate (detects presence of cytoplasmic starch that cleaves moieties from lipid soluble non-fluorescent probe to yield fluorescent product ${ }^{12}$ ). FDA analysis was made under fluorescence microscope (Olympus, model: MLXi with Micro-LED fluorescence attachment; excitation maximum $475 \mathrm{~nm}$, emission maximum $535 \mathrm{~nm})$.

Photomicrographs in all cases were taken and subsequently magnified.

\subsection{Crossing Experiments}

At anthesis ( 9 am to $11 \mathrm{am}$ ) reciprocal crossings between control and mutants ( 5 crosses in each set) were performed following all necessary precautionary measures to avoid genetic contaminations. Hybrid seeds obtained from crossings were sown to raise $F_{1}$ plant population and subsequently $\mathrm{F}_{2}$ (5 floral buds at $\mathrm{F}_{1}$ were bagged in each category) plants. The $\mathrm{F}_{2}$ plants segregated into normal and mutant phenotypes and $\chi^{2}$ test analysis has been performed to assess segregation patterns.

\subsection{Seed Protein Analysis}

Quantitative analysis of seed protein of the plant types was made following the extraction method suggested by Osborn ${ }^{13}$ and estimation by Lowry et al. ${ }^{14}$.

\subsubsection{SDS-PAGE}

The seed protein of 3 mutants along with control was used to study one dimentional SDS-PAGE (10\% separating gel; $4.5 \%$ stacking gel) following Laemmli ${ }^{15}$ in a vertical gel system (BIOTECH, Yercaud-Salem). For the purpose, total seed protein was extracted in $0.2 \mathrm{M}$ Tris buffer ( $\mathrm{pH} 8.5)$, suspended overnight $\left(-4^{\circ} \mathrm{C}\right)$ and centrifuged at $15,000 \mathrm{rpm}\left(-4^{\circ} \mathrm{C}\right)$ for 40 minutes. The protein samples along with sample buffer containing bromophenol blue were denatured in boiling water (1 minute), cooled and loaded in lanes with micropipette $(12 \mu \mathrm{l} /$ lane; $0.075 \mu \mathrm{g} / \mu \mathrm{l})$. A protein molecular weight marker (GENI Bangalore, Cat No. PMW-M) was also incorporated into the gel (as marker lane) as reference to detect molecular weights of the bands. The gel was run at 33 $\mathrm{mA}(3 \mathrm{~mA} /$ lane $)$ for about 3 hours, stained in Coomassie 
Brilliant Blue R250 for overnight, destained and stored in $7 \%$ acetic acid ${ }^{16}$. Gels were scored and analyzed in gel documentation unit (Ultra Lum, USA) using the software TotalLab ${ }^{\mathrm{TM}}$ Quant v 11.

\subsection{Molecular Analysis}

Total genomic DNA from 4 plant types (3 mutants and control; harvested seeds of a single plant of the mutants were used in each case in $M_{7}$; control- seeds from selfed lines of 2012) were isolated separately from $0.2 \mathrm{gm}$ of germinated seedlings using DNeasy Plant Mini Kit of Qiagen, USA. The seedlings were raised in Petri plates lined with moist filter papers $\left(27^{\circ} \pm 1^{\circ} \mathrm{C}\right)$. The mucilage and polyphenolic compounds were removed by passing DNA through an Au-Prep purification column (Life Technologies, Rockville, MD, USA). Subsequently, quality and quantity of extracted DNA were checked by running the dissolved DNA in $0.8 \%$ agarose gel by comparison with standard lambda DNA marker of known concentration. The DNA was diluted to $30 \mathrm{ng} / \mu \mathrm{l}$ for RAPD and ISSR analysis.

\subsubsection{RAPD and ISSR Analyses}

Ten base 30 RAPD primers (OPA 01-10, OPB 01-10, OPC 01-10; Operon Technologies, Alameda, USA) and 7 non anchored oligonucleotide ISSR primers (synthesized by Isogen) were used for Polymerase Chain Reaction (PCR). Amplification reactions were performed in volumes $25 \mu \mathrm{l}$ containing $2.5 \mu \mathrm{l}$ of $10 \mathrm{X}$ assay buffer (100 mM Tris-HCl; pH 8.3, 500 mM KCl, 15 mM $\mathrm{MgCl}_{2}$ ), $100 \mathrm{mM}$ (For RAPD) / $200 \mathrm{mM}$ (for ISSR) of each dNTPs (dATP, dCTP, dGTP and dTTP) (MB1 Ferment Inc., Maryland, USA) 5 pg of RAPD primer / $15 \mathrm{ng}$ of ISSR primer, 1.0 unit of Taq DNA polymerase (Bangalore Genei, India) and $30 \mathrm{ng}$ of template DNA from each plant types.

Amplification reactions and programming of 44 cycles for RAPD and 27 cycles for ISSR in a DNA Thermal Cycler (Eppendorf AG, Hamburg, Germany) were performed as suggested earlier in Corchorus spp. by Mandal et al. ${ }^{17}$. Three repeat runs were made and the primers documenting uniformity in band position and intensity were considered for analyses.

RAPD and ISSR bands were designated based on their molecular weight and calculated using the kilobase $(\mathrm{kb})$ ladder used as marker. Molecular data were processed in MS excel for calculating polymorphic band(s) of individual primer, average polymorphic band per primer and polymorphism percentage. Shannon's diversity index ${ }^{18}$ was calculated for each primer across the plant types.

\subsection{Chlorophyll Estimation and Pigment Profile by TLC}

Chlorophyll was extracted and estimated from leaf (1 gm for each sample, 3 replicas) tissues (of identical maturity) of control and 'viridis' ( $M_{7}$ generation plants) following the method Arnon ${ }^{19}$. The extraction of chlorophyll and carotenoid pigments for Thin Layer Chromatography (TLC) was performed as per Pavia et al. ${ }^{20}$. TLC was done from the extracted samples in triplicate as suggested by Fried and Sherma ${ }^{21}$. The mobile phase used in the chromatography was pet. ether : isopropanyl alcohol : water (9:1:5 drops). After complete run, the TLC plates were taken out of the chambers, air dried and spots of different colorations were observed and photographed. Rf values were calculated and compared with reference chart provided by Pavia et al. ${ }^{20}$ for quantitative plant pigment analysis.

\section{Results}

Seed germination frequencies are noted to be $84.00 \%$ to $85.00 \%$ and $68.00 \%$ to $72.00 \%$ in control, $63.00 \%$ to $65.00 \%$ and $58.00 \%$ to $61.00 \%$ in 'pigmented stem', $75.00 \%$ to $78.00 \%$ and $66.00 \%$ to $69.00 \%$ in 'viridis' and $68.00 \%$ to $71.00 \%$ and $54.00 \%$ to $58.00 \%$ in 'lax branching' mutants under Petri plate and field conditions respectively. Percentage of seed viability is found to be higher in control (98.0\% to 99.0\%) than the mutants ('pigmented stem' $-49.00 \%$ to $58.00 \%$, 'viridis' $-61.00 \%$ to $64.00 \%$; 'lax branching'- $51.00 \%$ to $53.00 \%$ ) across the generations.

\subsection{Analysis of Quantitative Parameters}

Data scored for morphometric traits of the plant types across the generations are presented in Table 1. Results indicated that 'lax branching' mutant (Figure 1d) is a productive plant type possessing enhances number of branches, seed and fiber yield per plant. 'Pigmented stem' (Figure 1b) is also with higher number of seeds/capsule and enhanced seed yield/plant. Apart from the significant marker color trait in 'viridis' plant type (Figure 1c), quantitative parameters are either less or comparable to control (Figure 1a). Analysis of each parameter in each 
plant type across generations suggests randomness $(P>05$, DF 2) in distribution. All mutants bred true across the generations.

\subsection{Meiosis and Pollen Attributes}

Meiotic configurations, pollen fertility and pollen viability of the plant types are presented in Table 2. The meiocytes had $2 \mathrm{n}=14$ chromosomes always (Figure $2 \mathrm{a}-\mathrm{d})$. Assessment of meiotic configurations at diplotene, MI and AI indicated that it is comparable among/ between plant types as well as among generations of each plant type. Bivalent configuration is predominantly rod rather than ring. Univalent frequency (0 to $14 /$ cell) is found to be higher in 'pigmented stem' than other plant types (Figure $2 \mathrm{c}-\mathrm{d}$ ). Pollen fertility (Figure $2 \mathrm{e}$ ) seems to be relatively lower in the mutants than control. However, pollen viability percentage assessed following stain tests (aniline blue - Figure 2f; FDA - Figure $2 \mathrm{~g}-\mathrm{h}$ ) is noted to be higher in 'lax branching' and 'pigmented stem' in comparison to control.

\subsection{Inheritance of Traits}

$\mathrm{F}_{1}$ plants in all sets of crossings were phenotypically alike to normal plants. $\mathrm{F}_{2}$ plants are found to segregate into either 3:1 (control as pollen parent $\times$ 'lax branching' as stigma parent: total 115 , normal 85 , mutant $30, \chi^{2}=0.072$ at $1 \mathrm{DF}, P>0.80$, reciprocal: total 97 , normal 70 , mutant 27 , $\chi^{2}=0.416$ at $1 \mathrm{DF}, P>0.50$; control as pollen parent $\times$ 'pigmented stem': total 167 , normal 130 , mutant $37, \chi^{2}=0.720$ at $1 \mathrm{DF}, P>0.30$, reciprocal: total 123 , normal 96 , mutant 27, $\chi^{2}=0.709$, DF $1, P>0.30$ ) or 15:1 (control as pollen parent $\times$ 'viridis' as stigma parent: total 243, normal 224, mutant $19, \chi^{2}=1.233$, DF $1, P>0.20$, reciprocal: total 137 , normal 125 , mutant $12, \chi^{2}=2.591$, DF $1, P>0.10$ ) ratio.

\subsection{Seed Protein Content}

Total seed protein content has been $8.97 \%$ in control, $9.83 \%$ in 'pigmented stem', $7.88 \%$ in 'viridis' and $6.62 \%$ in 'lax branching'; however, the quantified amount did not vary significantly among the plant types $\left(X^{2}=2.25\right.$, DF 3 , $P>0.05)$.

\subsection{Seed Protein Profile by SDS-PAGE}

Seed protein profile following SDS-PAGE (Figure 3) of C. olitorius (control) and 3 mutants (Table 3 ) resulted in 35 polypeptide bands with $\mathrm{Rf}$ value ranging from 0.066 to 0.981 (Molecular weight $14.49 \mathrm{kDa}$ to $133.64 \mathrm{kDa}$ ). The total number of detectable bands have been 29 in control, 20 in 'pigmented stem', 21 in 'viridis' and 16 in 'lax branching', and they are grouped into high (79.81-133.64 kDa), medium $(41.89-75.24 \mathrm{kDa})$ and low $(14.49-39.65 \mathrm{kDa})$ molecular weights. Most of the polypeptide bands are of low molecular weights. Polypeptide band no. 1, 2, 9, 13, $15,27,29$ and 35 are specific to control; while, band no. 7, 19 and 22 are specific to 'pigmented stem', 'viridis' and 'lax branching' respectively. Polypeptide band no. 18 and 31 are found common between control and 'pigmented stem' and 6 and 10 between 'viridis' and 'lax branching. Ten polypeptide bands are common to all plant types.

\subsection{Molecular Analyses}

RAPD (Figure 4a-b) and ISSR (Figure 4c) band profiles are presented in Tables 4 and 5 respectively. Out of 2 marker
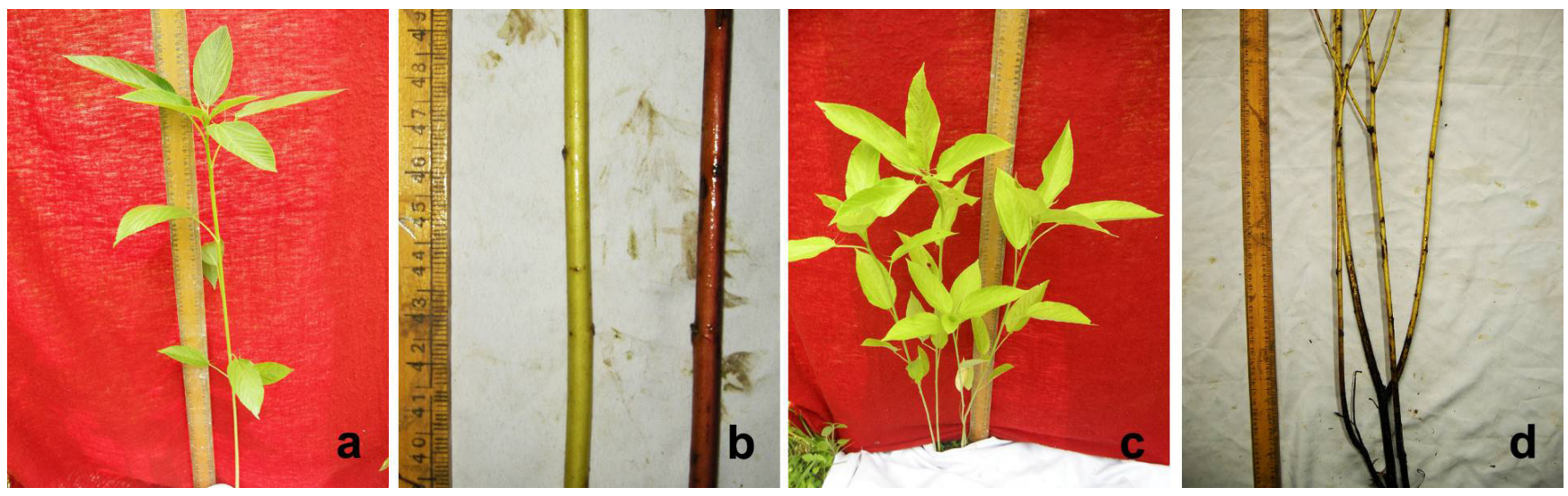

Figure 1. Plant types and traits in C. olitorius: (a) control plant, (b) Normal and pigmented stem color traits, (c) 'viridis' plant type, (d) lax branching trait. 


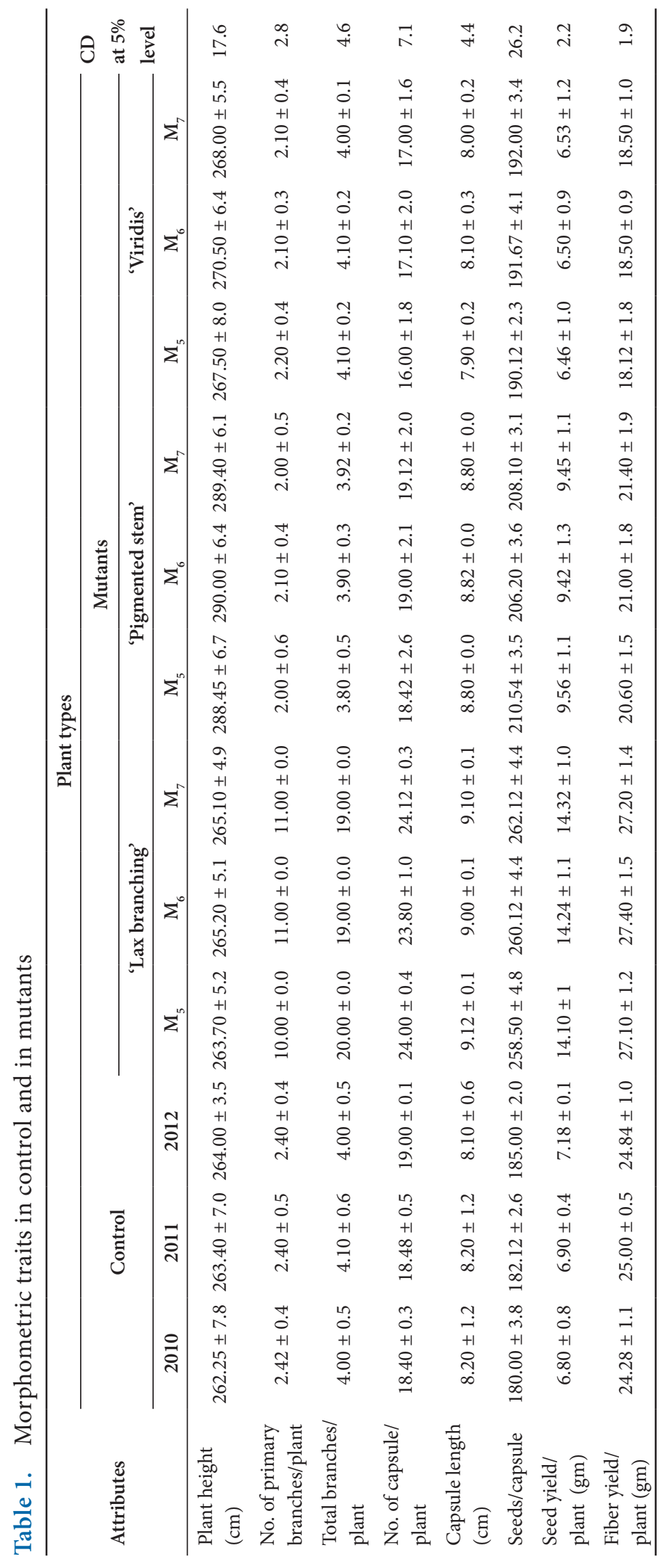


Table 2. Meiotic configurations, pollen fertility and viability in control (C. olitorius) and in three mutant plant types

\begin{tabular}{|c|c|c|c|c|c|c|c|c|c|c|c|c|c|c|c|c|}
\hline \multirow{4}{*}{ Attributes } & \multicolumn{16}{|c|}{ Plant types } \\
\hline & \multirow{2}{*}{\multicolumn{4}{|c|}{ C. olitorius }} & \multicolumn{12}{|c|}{ Mutants } \\
\hline & & & & & \multicolumn{4}{|c|}{ 'Lax branching' } & \multicolumn{4}{|c|}{ 'Pigmented stem' } & \multicolumn{4}{|c|}{ 'Viridis' } \\
\hline & 2010 & 2011 & 2012 & Pooled & $\mathrm{M}_{5}$ & $\mathrm{M}_{6}$ & $\mathrm{M}_{7}$ & Pooled & $\mathbf{M}_{5}$ & $\mathrm{M}_{6}$ & $\mathrm{M}_{7}$ & Pooled & $\mathbf{M}_{5}$ & $\mathrm{M}_{6}$ & $\mathbf{M}_{7}$ & Pooled \\
\hline \multicolumn{17}{|c|}{ Frequency/cell at diplotene } \\
\hline I & 0.12 & 0.48 & 0.39 & 0.33 & 0.00 & 0.02 & 0.00 & 0.01 & 0.21 & 0.04 & 0.00 & 0.08 & 1.13 & 0.26 & 0.06 & 0.34 \\
\hline II & 6.94 & 6.75 & 6.80 & 6.86 & 7.00 & 6.99 & 7.00 & 7.00 & 6.90 & 6.98 & 7.00 & 6.96 & 6.43 & 6.90 & 6.97 & 6.83 \\
\hline \multicolumn{17}{|c|}{ Bivalent configurations } \\
\hline Ring/cell & $\begin{array}{l}0.48 \pm \\
0.12\end{array}$ & $\begin{array}{l}0.33 \pm \\
0.10\end{array}$ & $\begin{array}{l}0.46 \pm \\
0.12\end{array}$ & $\begin{array}{l}0.43 \pm \\
0.11\end{array}$ & $\begin{array}{l}0.41 \pm \\
0.08\end{array}$ & $\begin{array}{l}0.23 \pm \\
0.05\end{array}$ & $\begin{array}{l}0.38 \pm \\
0.06\end{array}$ & $\begin{array}{l}0.33 \pm \\
0.07\end{array}$ & $\begin{array}{l}0.48 \pm \\
0.09\end{array}$ & $\begin{array}{l}0.28 \pm \\
0.05\end{array}$ & $\begin{array}{l}0.31 \pm \\
0.06\end{array}$ & $\begin{array}{l}0.35 \pm \\
0.08\end{array}$ & $\begin{array}{l}0.07 \pm \\
0.03\end{array}$ & $\begin{array}{l}0.35 \pm \\
0.08\end{array}$ & $\begin{array}{l}0.65 \pm \\
0.10\end{array}$ & $\begin{array}{l}0.57 \pm \\
0.09\end{array}$ \\
\hline Rod/cell & $\begin{array}{l}6.46 \pm \\
0.08\end{array}$ & $\begin{array}{l}6.43 \pm \\
0.06\end{array}$ & $\begin{array}{l}6.34 \pm \\
0.06\end{array}$ & $\begin{array}{l}6.41 \pm \\
0.07\end{array}$ & $\begin{array}{l}6.59 \pm \\
0.08\end{array}$ & $\begin{array}{l}6.76 \pm \\
0.05\end{array}$ & $\begin{array}{l}6.62 \pm \\
0.05\end{array}$ & $\begin{array}{l}6.66 \pm \\
0.06\end{array}$ & $\begin{array}{l}6.42 \pm \\
0.09\end{array}$ & $\begin{array}{l}6.70 \pm \\
0.08\end{array}$ & $\begin{array}{l}6.69 \pm \\
0.06\end{array}$ & $\begin{array}{l}6.17 \pm \\
0.07\end{array}$ & $\begin{array}{l}5.74 \pm \\
0.10\end{array}$ & $\begin{array}{l}6.52 \pm \\
0.10\end{array}$ & $\begin{array}{l}6.32 \pm \\
0.12\end{array}$ & $\begin{array}{l}6.26 \pm \\
0.10\end{array}$ \\
\hline $\begin{array}{l}\text { Mean } \\
\text { chiasma/cell }\end{array}$ & $\begin{array}{l}7.42 \pm \\
0.09\end{array}$ & $\begin{array}{l}7.09 \pm \\
0.12\end{array}$ & $\begin{array}{l}7.26 \pm \\
0.10\end{array}$ & $\begin{array}{l}7.27 \pm \\
0.10\end{array}$ & $\begin{array}{l}7.41 \pm \\
0.12\end{array}$ & $\begin{array}{l}7.22 \pm \\
0.10\end{array}$ & $\begin{array}{l}7.38 \pm \\
0.09\end{array}$ & $\begin{array}{l}7.33 \pm \\
0.10\end{array}$ & $\begin{array}{l}7.37 \pm \\
0.08\end{array}$ & $\begin{array}{l}7.26 \pm \\
0.08\end{array}$ & $\begin{array}{l}7.30 \pm \\
0.09\end{array}$ & $\begin{array}{l}7.31 \pm \\
0.08\end{array}$ & $\begin{array}{l}7.13 \pm \\
0.12\end{array}$ & $\begin{array}{l}7.22 \pm \\
0.09\end{array}$ & $\begin{array}{l}7.62 \pm \\
0.08\end{array}$ & $\begin{array}{l}7.40 \pm \\
0.09\end{array}$ \\
\hline $\begin{array}{l}\text { No. of cells } \\
\text { scored at } \\
\text { diplotene }\end{array}$ & 104 & 79 & 102 & 285 & 73 & 94 & 78 & 285 & 67 & 89 & 71 & 227 & 53 & 69 & 130 & 252 \\
\hline \multicolumn{17}{|c|}{ Mean association/cell at MI } \\
\hline I & 0.42 & 0.36 & 0.31 & 0.37 & 0.00 & 0.00 & 0.00 & 0.00 & 0.02 & 0.51 & 1.28 & 0.56 & 0.00 & 0.05 & 0.06 & 0.04 \\
\hline II & 6.97 & 6.82 & 6.85 & 6.82 & 7.00 & 7.00 & 7.00 & 7.00 & 6.87 & 6.74 & 6.40 & 6.72 & 7.00 & 6.98 & 6.97 & 6.98 \\
\hline $\begin{array}{l}\text { Predominant } \\
\text { association } \\
(7 \mathrm{II}) \text { at } \mathrm{MI} \\
(\%)\end{array}$ & 86.05 & 80.77 & 88.46 & 85.45 & 100.00 & 100.00 & 100.00 & 100.00 & 97.87 & 92.31 & 85.11 & 93.33 & 100.00 & 97.67 & 98.55 & 98.73 \\
\hline $\begin{array}{l}\text { Cells scored } \\
\text { at MI }\end{array}$ & 86 & 78 & 104 & 268 & 68 & 102 & 79 & 249 & 94 & 39 & 47 & 180 & 46 & 43 & 69 & 158 \\
\hline $\begin{array}{l}\text { Equal }(7 / 7) \\
\text { segregation of } \\
\text { chromosome } \\
\text { at } \mathrm{AI}(\%)\end{array}$ & 100.00 & 100.00 & 100.00 & 100.00 & 100.00 & 100.00 & 100.00 & 100.00 & 100.00 & 100.00 & 100.00 & 100.00 & 90.91 & 94.12 & 100.00 & 95.40 \\
\hline $\begin{array}{l}\text { Cells scored } \\
\text { at AI }\end{array}$ & 33 & 17 & 22 & 72 & 41 & 67 & 13 & 121 & 32 & 18 & 21 & 71 & 22 & 34 & 31 & 87 \\
\hline $\begin{array}{l}\text { Pollen fertility } \\
(\%)\end{array}$ & $\begin{array}{l}84.65 \\
(482)\end{array}$ & $\begin{array}{l}78.15 \\
(737)\end{array}$ & $\begin{array}{l}81.18 \\
(919)\end{array}$ & $\begin{array}{l}80.92 \\
(2138)\end{array}$ & $\begin{array}{l}69.67 \\
(854)\end{array}$ & $\begin{array}{l}69.88 \\
(800)\end{array}$ & $\begin{array}{l}71.81 \\
(908)\end{array}$ & $\begin{array}{l}70.49 \\
(2562)\end{array}$ & $\begin{array}{l}71.88 \\
(1280)\end{array}$ & $\begin{array}{l}69.94 \\
(1364)\end{array}$ & $\begin{array}{l}73.33 \\
(1226)\end{array}$ & $\begin{array}{l}71.65 \\
(3870)\end{array}$ & $\begin{array}{l}48.92 \\
(556)\end{array}$ & $\begin{array}{l}59.13 \\
(460)\end{array}$ & $\begin{array}{l}58.75 \\
(480)\end{array}$ & $\begin{array}{l}55.21 \\
(1496)\end{array}$ \\
\hline \multicolumn{17}{|c|}{ Pollen viability (\%) } \\
\hline Aniline blue & $\begin{array}{l}71.28 \\
(390)\end{array}$ & $\begin{array}{l}69.87 \\
(395)\end{array}$ & $\begin{array}{l}72.75 \\
(411)\end{array}$ & $\begin{array}{l}71.32 \\
(1196)\end{array}$ & $\begin{array}{l}77.04 \\
(331)\end{array}$ & $\begin{array}{l}80.94 \\
(299)\end{array}$ & $\begin{array}{l}81.03 \\
(290)\end{array}$ & $\begin{array}{l}82.71 \\
(885)\end{array}$ & $\begin{array}{l}82.42 \\
(330)\end{array}$ & $\begin{array}{l}82.47 \\
(365)\end{array}$ & $\begin{array}{l}94.62 \\
(316)\end{array}$ & $\begin{array}{l}86.25 \\
(1011)\end{array}$ & $\begin{array}{l}66.67 \\
(180)\end{array}$ & $\begin{array}{l}64.61 \\
(178)\end{array}$ & $\begin{array}{l}68.53 \\
(197)\end{array}$ & $\begin{array}{l}66.67 \\
(555)\end{array}$ \\
\hline $\begin{array}{l}\text { Fluorescene } \\
\text { diacetate } \\
\text { (FDA) }\end{array}$ & $\begin{array}{l}54.82 \\
(197)\end{array}$ & $\begin{array}{l}58.94 \\
(207)\end{array}$ & $\begin{array}{l}66.62 \\
(188)\end{array}$ & $\begin{array}{l}60.64 \\
(592)\end{array}$ & $\begin{array}{l}60.70 \\
(201)\end{array}$ & $\begin{array}{l}71.49 \\
(249)\end{array}$ & $\begin{array}{l}76.21 \\
(227)\end{array}$ & $\begin{array}{l}69.87 \\
(677)\end{array}$ & $\begin{array}{l}60.48 \\
(167)\end{array}$ & $\begin{array}{l}64.45 \\
(220)\end{array}$ & $\begin{array}{l}63.31 \\
(245)\end{array}$ & $\begin{array}{l}60.60 \\
(632)\end{array}$ & $\begin{array}{l}31.97 \\
(244)\end{array}$ & $\begin{array}{l}54.22 \\
(249)\end{array}$ & $\begin{array}{l}58.37 \\
(245)\end{array}$ & $\begin{array}{l}48.24 \\
(738)\end{array}$ \\
\hline
\end{tabular}

Values in the parenthesis indicates number of pollen grains scored 


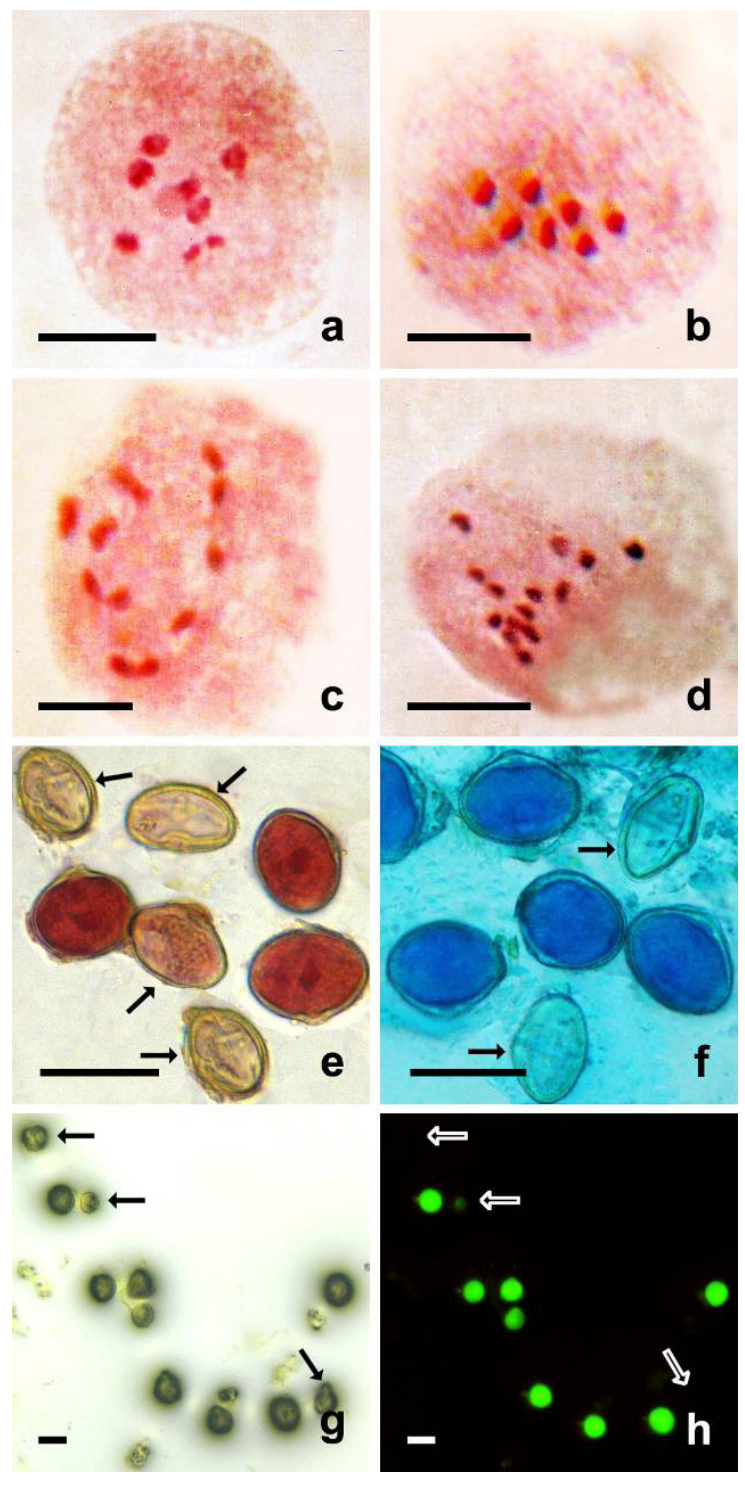

Figure 2. Meiotic configurations, pollen fertility and pollen viability in control and mutant plants: (a) 7II at diplotene, (b) 7II at MI, (c) 5II+6I at diakinesis, (d) 14I at MI, (e) fertile and sterile $(\rightarrow)$ pollen grains, (f) viable and non-viable $(\rightarrow)$ pollen grains following aniline blue staining, ( $\mathrm{g}-\mathrm{h})$ viable and nonviable $(\rightarrow)$ pollen grains stained in FDA. Scale bar $=10 \mu \mathrm{m}$ (Figure 2a-d); Scale bar $=40 \mu \mathrm{m}$ (Figure $2 \mathrm{~d}-\mathrm{h}$ ). systems employed, 23 out of 30 RAPD and 5 out of 7 ISSR primers yielded distinct scorable bands across control and 3 mutant plant types. The RAPD primers produced a total of 183 markers (control: 138-75.41\%; 'pigmented stem': 150-81.97\%; 'viridis': 147-80.33\%; 'lax branching': $146-79.78 \%)$ of which $85(46.45 \%)$ are polymorphic, whereas the ISSR primers documented 42 markers (control: 31-73.81\%; 'pigmented stem': 23-54.76\%; 'viridis': 31-73.81\%; 'lax branching': 30-71.43\%) of which 24 are polymorphic (57.14\%). Polymorphism has been found to vary from $11.11 \%$ (OPB 01) to $92.31 \%$ (OPB 03) among RAPD primers; while, it ranges from 42.86\% [(CAA) $)_{5}$ to $72.73 \%\left[(\mathrm{GA})_{12}\right]$ among ISSR markers. The average number of fragments amplified by RAPD primers across plant types was 7.96 with a range of 4 to 16 markers (size $220 \mathrm{bp}$ to $4800 \mathrm{bp}$ ). ISSR generated 6 to 11 markers (520 bp to $4200 \mathrm{bp}$ ) with an average of 8.4 per primer. Among the RAPD primers, OPB 03 (92.31\%), OPC 07 $(60.00 \%)$ and OPC 08 (60.00\%) have shown higher range of polymorphism; while, (GATA) $4-62.50 \%$ and $(\mathrm{GA})_{12}$ $72.73 \%$ documented maximum polymorphism across plant types. Shannon diversity index is rather comparable among RAPD (1.337 to 1.369; Table 4) and ISSR (1.319 to 1.396; Table 5) primers.

\subsection{Chlorophyll Content and Pigment Profile in Control and 'Viridis'}

Chlorophyll content $(\mathrm{mg} / \mathrm{gm})$ is found to vary significantly (chlorophyll a: 2.367 in control, 0.966 in 'viridis', $\mathrm{t}=7.04, \mathrm{DF}=4, P<0.001$; chlorophyll b: 0.645 in control, 0.197 in 'viridis', $\mathrm{t}=7.77, \mathrm{DF}=4, P<0.001$; total: 3.012 in control, 1.161 in 'viridis') between the plant types. A preliminary observation has been made to compare the pigment profiles of 'viridis' with control qualitatively based on TLC (Table 6; Figure 5). Number of spots, Rf values and color of the spots under UV-visible spectra are analyzed based on reference chart. Results showed a total of 7 spots (Rf 0.22 to 0.97 ) in control and 5 spots (Rf 0.56

Table 3. Number and types (based on molecular weight) of polypeptide bands in 4 plant types of C. olitorius

\begin{tabular}{lcccc}
\hline \multirow{2}{*}{ Genotypes } & \multicolumn{4}{c}{ Molecular weight (kDa) } \\
\cline { 2 - 4 } & High (79.81 kDa-133.64) & Medium (41.89 kDa-75.24 kDa) & Low $(14.49 \mathrm{kDa}-39.65 \mathrm{kDa})$ & Total \\
\hline C. olitorius (control) & 6 & 10 & 13 & 29 \\
'Pigmented stem' & 4 & 6 & 10 & 20 \\
'Viridis' & 3 & 7 & 11 & 21 \\
'Lax branching' & 3 & 3 & 10 & 16 \\
\hline
\end{tabular}




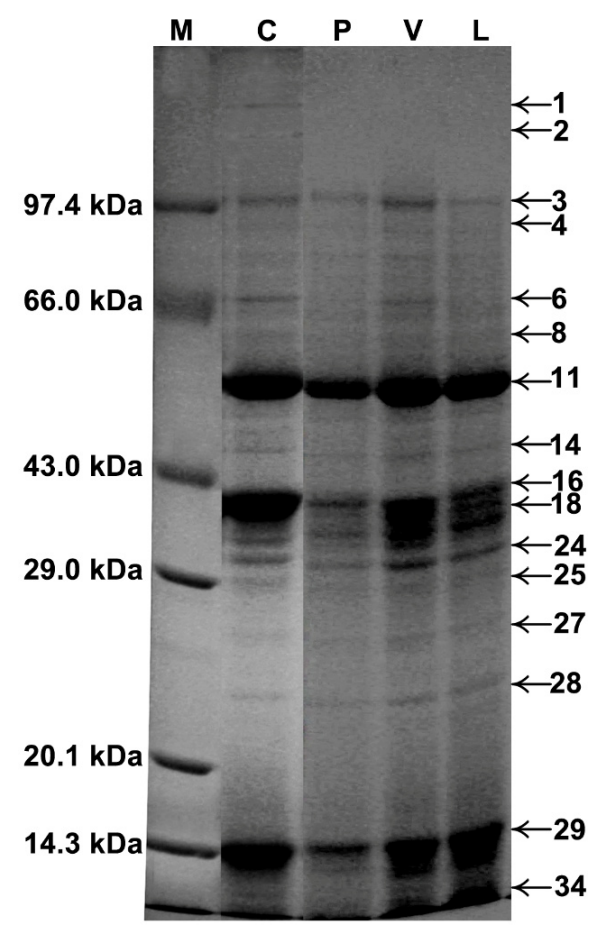

Figure 3. Band profile of seed storage protein following SDS-PAGE: (M) protein weight marker, (C) control, (P) 'pigmented stem', (V) 'viridis', (L) 'lax branching.'

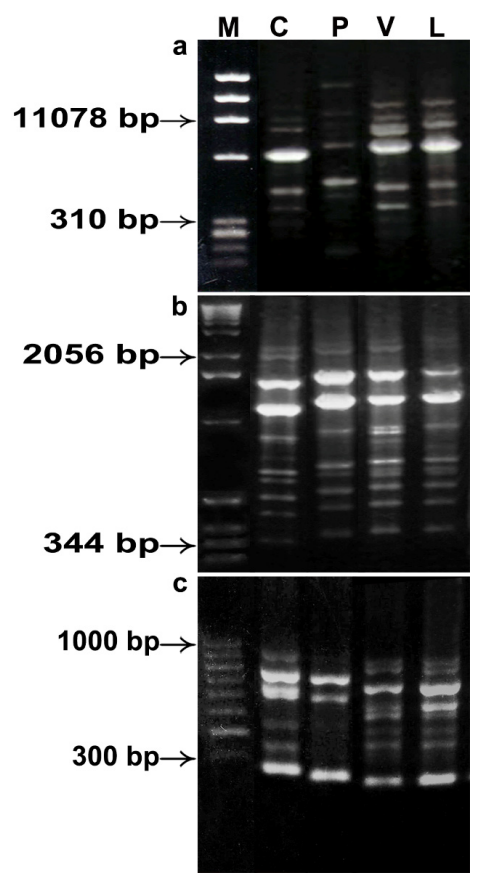

Figure 4. Band profile using RAPD (a OPB 03, b OPB 06) and ISSR [c (GA) ${ }_{12}$ ) primer in C. olitorius plant types: $(\mathrm{M})$ DNA molecular weight marker, (C) control, (P) 'pigmented stem', (V) 'viridis'; (L) 'lax branching'.

Table 4. RAPD profile in control and mutant plant types of C. olitorius

\begin{tabular}{|c|c|c|c|c|c|c|c|c|c|}
\hline \multirow[b]{2}{*}{ Primer } & \multirow[b]{2}{*}{ Sequence $\left(5^{\prime}-3^{\prime}\right)$} & \multirow{2}{*}{$\begin{array}{l}\text { Total no. of } \\
\text { bands scored }\end{array}$} & \multirow{2}{*}{$\begin{array}{l}\text { No. of } \\
\text { polymorphic } \\
\text { band }\end{array}$} & \multirow{2}{*}{$\begin{array}{l}\text { Polymorphism } \\
(\%)\end{array}$} & \multicolumn{4}{|c|}{ No. of bands scored in the plant types } & \multirow[b]{2}{*}{$\begin{array}{l}\text { - Shannon } \\
\text { index }\end{array}$} \\
\hline & & & & & C. olitorius & $\begin{array}{l}\text { 'Pigmented } \\
\text { stem' }\end{array}$ & 'Viridis' & $\begin{array}{l}\text { 'Lax } \\
\text { branching' }\end{array}$ & \\
\hline OPA-01 & CAGGCCCTTC & 9 & 4 & 44.44 & 7 & 8 & 7 & 7 & 1.384 \\
\hline OPA-02 & TGCCGAGCTG & 4 & 2 & 50.00 & 3 & 4 & 2 & 4 & 1.348 \\
\hline OPA-03 & AGTCAGCCAC & 8 & 4 & 50.00 & 6 & 7 & 5 & 8 & 1.369 \\
\hline OPA-04 & AATCGGGCTG & 11 & 6 & 54.55 & 10 & 9 & 8 & 6 & 1.368 \\
\hline OPA-05 & AGGGGTCTTG & 8 & 4 & 50.00 & 5 & 8 & 5 & 7 & 1.365 \\
\hline OPA-06 & GGTCCCTGAC & 9 & 3 & 33.33 & 6 & 8 & 8 & 7 & 1.394 \\
\hline OPA-07 & GAAACGGGTG & 8 & 4 & 50.00 & 7 & 6 & 5 & 6 & 1.352 \\
\hline OPA-10 & GTGATCGCAG & 6 & 2 & 33.33 & 4 & 5 & 6 & 6 & 1.385 \\
\hline OPB-01 & GTTTCGCTCC & 9 & 1 & 11.11 & 8 & 8 & 9 & 9 & 1.386 \\
\hline OPB-02 & TGATCCCTGG & 8 & 4 & 50.00 & 4 & 7 & 7 & 7 & 1.361 \\
\hline OPB-03 & CATCCСССТG & 13 & 12 & 92.31 & 9 & 5 & 11 & 8 & 1.337 \\
\hline OPB-04 & GGACTGGAGT & 10 & 3 & 30.00 & 10 & 9 & 9 & 7 & 1.391 \\
\hline OPB-05 & TGCGCCCTTC & 6 & 1 & 16.67 & 5 & 6 & 6 & 6 & 1.383 \\
\hline OPB-06 & TGCTCTGCCC & 16 & 6 & 37.50 & 12 & 10 & 15 & 12 & 1.361 \\
\hline OPC-01 & TTCGAGCCAG & 7 & 3 & 42.86 & 4 & 6 & 5 & 5 & 1.377 \\
\hline OPC-03 & GGGGGTCTTT & 7 & 2 & 28.57 & 6 & 6 & 6 & 7 & 1.385 \\
\hline OPC-04 & CCGCATCTAC & 5 & 1 & 20.00 & 4 & 4 & 5 & 4 & 1.396 \\
\hline OPC-05 & GATGACCGCC & 9 & 5 & 55.56 & 6 & 8 & 7 & 7 & 1.380 \\
\hline OPC-06 & GAACGGACTC & 8 & 4 & 50.00 & 5 & 7 & 6 & 6 & 1.380 \\
\hline OPC-07 & GTCCCGACGA & 5 & 3 & 60.00 & 3 & 5 & 4 & 3 & 1.364 \\
\hline OPC-08 & TGGACCGGTG & 5 & 3 & 60.00 & 4 & 4 & 3 & 4 & 1.393 \\
\hline OPC-09 & CTCACCGTCC & 7 & 4 & 57.14 & 5 & 5 & 4 & 5 & 1.368 \\
\hline OPC-10 & TGTCTGGGTG & 7 & 4 & 57.14 & 5 & 5 & 4 & 5 & 1.368 \\
\hline Total & & 183 & 85 & 46.45 & 138 & 150 & 147 & 146 & \\
\hline
\end{tabular}


Table 5. ISSR profile in control and mutant plant types of C. olitorius

\begin{tabular}{|c|c|c|c|c|c|c|c|c|c|}
\hline \multirow[b]{2}{*}{ Primer } & \multirow[b]{2}{*}{$\begin{array}{l}\text { Sequence } \\
\left(5^{\prime}-3^{\prime}\right)\end{array}$} & \multirow[b]{2}{*}{$\begin{array}{l}\text { Total no. of } \\
\text { bands scored }\end{array}$} & \multirow{2}{*}{$\begin{array}{l}\text { No. of } \\
\text { Polymorphic } \\
\text { bands }\end{array}$} & \multirow[b]{2}{*}{ Polymorphism (\%) } & \multicolumn{4}{|c|}{ No. of bands scored in the plant types } & \multirow{2}{*}{$\begin{array}{l}\text { Shannon } \\
\text { index }\end{array}$} \\
\hline & & & & & $\begin{array}{l}\text { C. olitorius } \\
\text { (Control) }\end{array}$ & $\begin{array}{l}\text { 'Pigmented } \\
\text { stem' }\end{array}$ & 'Viridis' & $\begin{array}{l}\text { 'Lax } \\
\text { branching' }\end{array}$ & \\
\hline No. 1 & $(\mathrm{CAA})_{5}$ & 7 & 3 & 42.86 & 7 & 4 & 5 & 5 & 1.366 \\
\hline No. 2 & $(\mathrm{GA})_{12}$ & 11 & 8 & 72.73 & 7 & 3 & 9 & 9 & 1.319 \\
\hline No. 3 & $(\mathrm{CA})_{8} \mathrm{GC}$ & 10 & 5 & 50.00 & 7 & 7 & 7 & 6 & 1.384 \\
\hline No. 4 & $(\mathrm{GATA})_{4}$ & 8 & 5 & 62.50 & 6 & 5 & 5 & 6 & 1.384 \\
\hline No. 5 & $(\mathrm{GAA})_{6} \mathrm{G}$ & 6 & 3 & 50.00 & 4 & 4 & 5 & 4 & 1.396 \\
\hline Total & & 42 & 24 & 57.14 & 31 & 23 & 31 & 30 & \\
\hline
\end{tabular}

to 0.97$)$ in 'viridis'. It seems that 2 yellow colored spots ( $\mathrm{Rf}$ 0.22 - Neoxanthin; Rf 0.41 - Violaxanthin) which are present in control are rather lacking in 'viridis'. Color intensity of the spots is less in 'viridis' than control.

\section{Discussion}

Analysis of quantitative parameters in control and mutants across the years suggested that 'lax branching' mutant is a productive plant type as it possesses enhance number of capsule per plant and seed and fibre yield per plant compared to control. Capsule per plant and seed yield per plant are also found to increase in 'pigmented stem'. Estimation of chlorophyll content and preliminary analysis of pigment profile following TLC revealed significant variations between 'viridis' and control plant types. Leaf and stem colors of the raised and maintained 'viridis' and 'pigmented stem' mutants respectively are important as they may be explore as genetic markers in efficient breeding program of C. olitorius. Random distribution of quantitative traits, high frequency of 7II formation in meiocytes along with high pollen fertility and viability in mutants across generations suggested stability of the plant types. Further, seed germination frequency and seed viability percentage in mutants indicated that they are well acclimatized under the grown environmental condition(s). Macromutants namely, 'crumple leaf' and 'tobacco leaf', 'narrow leaf', 'KOM $62^{\prime 5}$ among others have been reported in C. olitorius. Thus, the mutants described are new to the species.

Lax branching and pigmented stem traits segregated at $\mathrm{F}_{2}$ to a close fit of 3:1 ratio thereby, indicating monogenic recessive inheritance of the mutant traits. However, 'viridis' showed digenic (15:1) mode of inheritance. Results of reciprocal crossings are found to be similar, which suggested that the trait(s) are under nuclear gene control. Most mutation involving qualitative traits in C. olitorius are reported to be monogenic recessive excepting for 'leaf surface', 'rolled leaf' and 'fuzzy seed coat', which showed digenic mode of inheritance ${ }^{22}$. Hazra and Karmakar $^{22}$ also reported that genetics of anthocyanin pigmentation in the species is rather complex and seems to involve 56 genes.

Apart from possessing lax branching nature and seedling and stem color traits, the mutants are concomitantly associated with other qualitative and quantitative traits. Kreft et al. ${ }^{23}$ suggested that high lysine genes in barley and genes for the determinant growth in buck wheat (Fagopyrum esculentum) were suitable examples to show that the effect of single mutation could be complex or 'pleiotropic'. Pleiotropic gene action was found to influence stem, petiole, and bract tip pigmentation of sunflower ${ }^{24}$. Stearn $s^{25}$ suggested the potential significance of pleiotropic gene action on evolutionary biology.

Seed protein content does not vary significantly among the plant types. However, seed protein profile following SDS-PAGE showed mark variations among/between plant types. Specific polypeptide bands are identified in control as well as in different mutants, apart from possessing common bands. Seed protein expression resulting in the formation of polypeptide bands is considered to be dominant over non-expression ${ }^{26}$. Mutation in regulatory and/ or structural genes may lead to failure of protein expres$\operatorname{sion}^{27}$. In the context, it may be inferred that presence or absence of polypeptide band(s) in different mutants in relation to control can be use as reliable marker for their identification and preparation of protein profiles.

Molecular analyses of the plant types using RAPD and ISSR markers indicated distinctive genetic variations (variation in the number of fragments generated) 
Table 6. Pigment profile following TLC

\begin{tabular}{lcllcc}
\hline \multirow{2}{*}{$\begin{array}{l}\text { No. of } \\
\text { spot }\end{array}$} & Rf & Color* & Pigment & \multicolumn{2}{c}{ Plant types } \\
\cline { 3 - 5 } 1 & 0.97 & Golden & $\beta$-carotene & + & + \\
2 & 0.74 & Olive green & Pheophytin & + & + \\
3 & 0.68 & Blue green & Chlorophyll a & + & + \\
4 & 0.63 & Yellow green & Chlorophyll b & + & + \\
5 & 0.56 & Yellow & Lutein & + & + \\
6 & 0.41 & Yellow & Violaxanthin & + & - \\
7 & 0.22 & Yellow & Neoxanthin & + & - \\
\hline
\end{tabular}

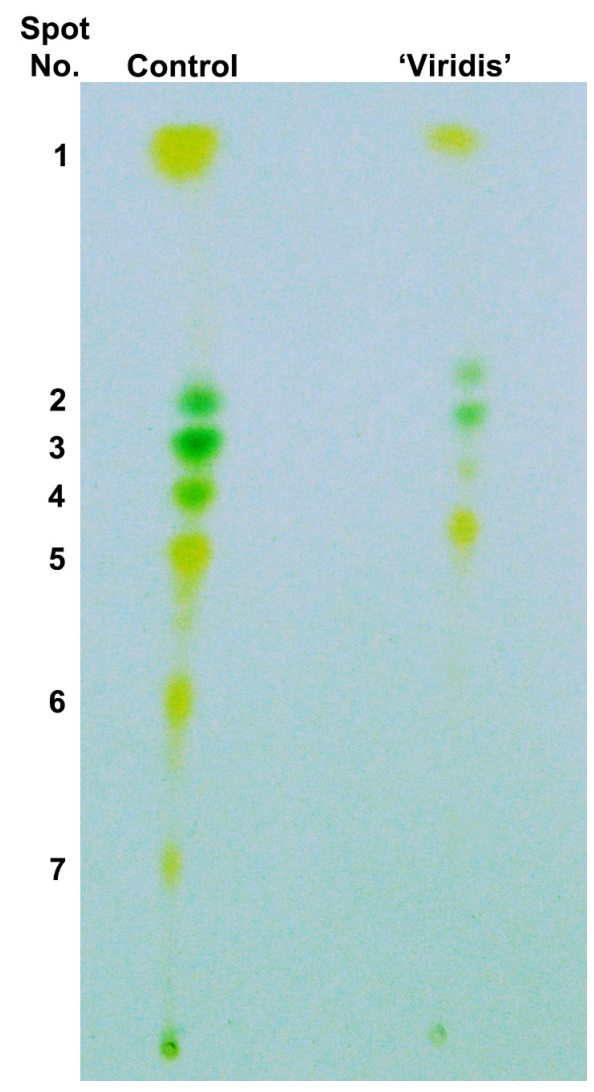

Figure 5. TLC pigment profile in control and 'viridis'.

between/among the mutants as well as between mutants and control. Average polymorphism percentage is found to be $46.45 \%$ by RAPD and $57.14 \%$ by ISSR primers. RAPD markers generated wide range of variations $(11.11 \%$ to $92.31 \%$ ) than ISSR ( $42.86 \%$ to $72.73 \%$ ) across the plant types. RAPD markers are used to assess genetic variations caused due to mutation in different plant species ${ }^{28-30}$.
Sen and Alikamanoglu ${ }^{31}$ performed analysis of drought tolerant sugar beet (Beta vulgaris) mutants induced with gamma irradiation using SDS-PAGE and ISSR markers and found wide range of polymorphism in the band profiles.

\section{Conclusion}

The macromutants are true breeding and stable. Seed protein analysis by SDS-PAGE and molecular analyses following the use of RAPD and ISSR markers suggests distinctive genetic variations between/among the plant types. 'Lax branching' mutant is found to be a productive in relation to seed and fibre yield, although plantation per unit area may not be promising. 'Viridis' and 'pigmented stem' mutants possessing genetic marker trait(s) can be important resources in efficient breeding program in C. olitorius. The mutants may be recommended as 'new plant types', enriching genetic resources in the species.

\section{Acknowledgement}

The research is grant aided by University Grants Commission, New Delhi, India and DST-PURSE Programme, University of Kalyani, West Bengal, India.

\section{References}

1. Kharkwal MC. Impact of mutation breeding in global agriculture. Paper presented at: National Symposium on Plant cytogenetics: New Approaches; 2012 Feb 23-24; Department of Botany, Punjabi University, Patiala, India.

2. Wallace DR. The romance of jute. Calcutta: Indian Central Jute Committee; 1909.

3. Basak SL. Review on the genetics and breeding of jute. Dhaka, Bangladesh: International Jute Organization; 1993.

4. Chattopadhyay S, Chaudhury SK, Gupta D, Hazra SK, Kumar D, Mahapatra AK, Mandal N, Saha A. Crop improvement. Fifty years of research. Barrackpore, India: CRIJAF; 1999.

5. Chowdhury SK, Kumar D, Saha A. Varietal development and improved varieties of jute. Technical Bulletin Series. CRIJAF; 2004.

6. Sinhamahapatra SP. Development of desirable strain in jute C. capsularis L. using mutants in cross breeding. J Nucl Agr Biol. 2005; 34(2):111-14.

7. Singh DP, Sharma BK, Banerjee SC. X-ray induced mutations in jute (C. capsularis and C. olitorius). Genet Agrar. 1973; 27(2-3):115-47. 
8. Maity S, Datta AK. Induced viable macromutants in Corchorus olitorius L. Journal of Phytological Research. 2009; 22(1), 43-6.

9. Patil VN, Dadlani M. Tetrazolium test for seed viability and vigour. Handbook of Seed Testing; 2009.

10. Marks GE. An aceto-carmine glycerol jelly for use in pollen-fertility counts. Stain Tech. 1954; 29(5):277-78.

11. Bengtsson S. Evaluation of transgenic Campanula carpatica plants. [Epsilon Undergraduate Theses]. Dept. of Agricultural Sciences, The Royal Veterinary and Agricultural University; 2006, Archive: vol. 6.

12. Coder DM. Assessment of Cell Viability. In: Robinson JP, Darzynkiewicz Z, Hoffman R, Nolan JP, Rabinovitch PS, Watkins S, editors. Current Protocols in Cytometry, New York (NY): Core Publication, John Wiley \& Sons, Inc; 1997. p. 9.2.1-9.2.14.

13. Osborne DJ. Effect of kinetin on protein and nucleic acid metabolism in Xanthium leaves during senescence. Plant Physiol. 1962; 37(5):595-602.

14. Lowry OH, Rosenbrough NJ, Farr AL, Randall RJ. Protein measurement with the Folin phenol reagent. J Biol Chem. 1951; 193(1):265-75.

15. Laemmli U K. Cleavage of structural proteins during the assembly of the head of bacteriophage T 4 . Nature. 1970; 227(5259):680-85.

16. Tal H, Silberstein A, Nusser E. Why does Coomassie Brilliant Blue $\mathrm{R}$ interact differently with different protein? A partial answer. J Biol Chem. 1985; 260(18):9976-80.

17. Mandal A, Datta AK, Datta S, Gupta S. Genetic assessment of eight Corchorus spp. (Tiliaceae) using RAPD and ISSR markers. Nucleus. 2013; 56(1):23-30.

18. Martynov SP, Dobrotvorskaya TV, Dotlacil L, Stehno Z, Faberova I, Bares I. Genealogical approach to the formation of the winter wheat core collection. Russian Journal of Genetics. 2003; 39(8):917-23.

19. Arnon DI. Copper enzyme in isolated chloroplast. Polyphenol oxidase in Beta vulgaris. Plant Physiol. 1949; 24(1):1-15.
20. Pavia DL, Lampman GM, Kriz GS, Engel RG. Introduction to organic laboratory techniques: a microscale approach. 3rd ed. New York, NY: Saunders College Publishing; 1999.

21. Fried B, Sherma J. Thin-layer chromatography (Revised and Expanded). 4th ed. New York-Basel: Marcel Dekker Inc; 1999.

22. Hazra SK, Karmakar PG. Cytogenetics, mutagenesis and genetics of qualitative characters of jute and allied fiber crops. In: Karmakar PG, Hazra SK, editors. Jute and allied fiber updates. Barrackpore, Kolkata, India: CRIJAF; 2008.

23. Kreft I, Javornik B, Kajfez-Bogataj L. Ripening and yield in barley with high-lysine gene lys-3a. Barley Genetics Newsletter. 1985; 15:645-7.

24. Deveraja TV, Goud S. Pleiotropic gene and its influence on stem, petiole and bract tip pigmentation in sunflower (Helianthus annuus L.). Helia. 2005; 28(43):107-12.

25. Stearns F. One hundred years of pleiotropy: a retrospective. Genetics. 2010; 186(3):767-73.

26. Osborn TC, Brown JWS. Genetic control of bean seed protein. Crit Rev Plant Sci. 1988; 7(2):93-16.

27. Brown JWS, Bliss FA, Hall TC. Linkage relationships between genes controlling seed proteins in French bean. Theor Appl Genet. 1981; 60(4):251-59.

28. Oksana D, Sorschink B. Use of RAPD assay for the detection of mutation changes in plant DNA induced by UV-B and Gamma - Rays. BMC Plant Biol. 2005; 5(1):S9.

29. Dhakshanamoorthy D, Selvaraj R. Use of RAPD marker for identification of DNA polymorphism in gamma rays treated Jatropha curcas L. Indian Journal of Plant Physiology. 2010; 15(3):283-87.

30. Bhatt KD, Girnari SK, Mandaliya VB, Chariya LD, Thaker VS. Use of RAPD marker to confirm mutation in morphological variants on Neem tree. Electron J Plant Breed. 2011; 2(3):473-78.

31. Sen A, Alikamanoglu S. Analysis of drought-tolerant sugar beet (Betavulgaris L.) mutantsinduced with gamma radiation usingSDS-PAGEandISSRmarkers. MutatRes.2012Oct-Nov; 738-39, 38-44. 